Research Article

\title{
Sensitivity Approach of Optical Sensors of Cholesterol Detection through Gaussian Beam and Quasi-Gaussian Beam
}

\author{
Mohammad Budiyanto ${ }^{1, a}$, Mohamad Yasin ${ }^{2, b}$, and Sulaiman Wadi Harun ${ }^{3, c}$ \\ ${ }^{1}$ Department of Natural Sciences, Faculty of Mathematics and Natural Sciences, Universitas Negeri Surabaya \\ Jalan Ketintang, Surabaya 60231, Indonesia \\ ${ }^{2}$ Department of Physics, Faculty of Sciences and Technology, Universitas Airlangga, Indonesia \\ Kampus C, Jl. Unair, Surabaya 60115, Indonesia \\ ${ }^{3}$ Photonics Engineering Laboratory, Department of Electrical Engineering, Faculty of Engineering, \\ University of Malaya \\ University of Malaya, Kuala Lumpur 50603, Malaysia \\ e-mail: ${ }^{a}$ mohammadbudiyanto@unesa.ac.id, ${ }^{\mathrm{b}}$ yasin@,fst.unair.ac.id, and ${ }^{\mathrm{c}}$ swharun@um.edu.my
}

\begin{abstract}
Sensitivity is the comparison result between changes in output signal intensity and changes in input signal shift sensor. The purpose of this study was to analyze the sensitivity of fiber optic sensors using mathematical analysis through the Gaussian beam approach and quasi-Gaussian beam compared with the sensitivity of the optical sensor experimental results so that it can find the correct approach of sensitivity values between theory and experiment. The research method used mathematical analysis and experimental methods and mathematical descriptions for the description of the bundle optical fiber used in the experiment until the sensitivity equation is obtained. The results of the mathematical analysis of the Gaussian beam sensitivity values obtained of $S=0.004 \mathrm{mV} \mathrm{ppm}^{-1}$ and the sensitivity of quasi-Gaussian beam of $S=0.08 \mathrm{mV} \mathrm{ppm}^{-1}$. The results of the sensitivity of experimentally obtained $S=0.11 \mathrm{mV} \mathrm{ppm}{ }^{-1}$. Based on the results of mathematical, experimental analysis, and sensor performance, sensitivity through the flat mirror reflection field, it can be concluded that the sensitivity of the optical fiber sensor tends to approach through the quasi-Gaussian beam approach to determine cholesterol concentration.
\end{abstract}

Keywords: sensitivity, Gaussian beam, Quasi Gaussian beam, cholesterol

\section{Pendekatan Sensitivitas Sensor Optik Deteksi Kolesterol Melalui Gaussian Beam dan Quasi Gaussian Beam}

\begin{abstract}
Abstrak
Sensitivitas hasil perbandingan antara perubahan intensitas sinyal keluaran terhadap perubahan sinyal masukan pergeseran sensor. Tujuan penelitian ini untuk menganalisis sensitivitas sensor serat optik dengan menggunakan analisis matematis melalui pendekatan Gaussian Beam dan Kuasi Gaussian Beam dibandingkan dengan sensitivitas sensor optik hasil eksperimen sehingga dapat mengetahui pendekatan yang benar nilai sensitivitas antara teori dan eksperimen. Metode penelitian menggunakan analisis matematis dan metode ekspeimen dengan deskripsi matematis untuk deskripsi serat optik bundle yang digunakan pada eksperimen sampai diperoleh persamaan sensitivitas. Hasil analisis
\end{abstract}

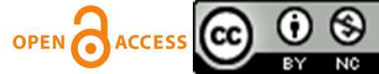


Jurnal Penelitian Fisika dan Aplikasinya (JPFA), 2019; 9(1): 22-31

matematis nilai sensitivitas Gaussian beam diperoleh $S=0,0004 \mathrm{mV} \mathrm{ppm}^{-1}$ dan sensitivitas Quasi Gaussian beam $S=0,08 \mathrm{mV} \mathrm{ppm}^{-1}$. Adapun hasil sensitivitas secara eksperimen diperoleh $S=0,11 \mathrm{mV} \mathrm{ppm}^{-1}$. Berdasarkan hasil analisis matematis dan eksperimen dan kinerja sensor, sensitivitas melalui bidang pantul cermin datar maka dapat disimpulkan bahwa sensitivitas sensor serat optik cendrung mendekati melalui pendekatan berkas Quasi Gaussian untuk menentukan konsentrasi kolesterol.

Kata Kunci: sensitivitas, Gaussian beam, Quasi Gaussian beam, kolesterol

PACS: 42.81.Pa, 42.81.Qb, 42.81.Wg

(C) 2019 Jurnal Penelitian Fisika dan Aplikasinya (JPFA). This work is licensed under CC BY-NC 4.0

Article History: Received: November 2, 2018

Accepted: June 27, 2019
Approved with minor revision: May 13, 2019

Published: June 30, 2019

How to Cite: Budiyanto M, Yasin M, and Harun SW. Sensitivity Approach of Optical Sensors of Cholesterol Detection through Gaussian Beam and Quasi-Gaussian Beam. Jurnal Penelitian Fisika dan Aplikasinya (JPFA). 2019; 9(1): 22-31. DOI: https://doi.org/10.26740/jpfa.v9n1.p22-31.

\section{INTRODUCTION}

Optical fiber includes type of cable for wave transmission or wave reflection channels made of glass and plastic. Optical fiber serves to guide electromagnetic waves with very fine shapes and sizes and can be used to transmit light signals from one place to other. The light source that passes through optical fibers is usually in the form of laser. This optical fiber is about 120 micrometers in diameter. The light inside the optical fiber does not come out because the refractive index of the glass is bigger than the refractive index of the air. In principle, optical fibers reflect and refract a number of light that propagates in them. The efficiency of optical fibers is determined by the purity of the glass or glass constituent. The purer the glass material of the fiber, the less light is absorbed by the optical fiber.

Applied research on fiber optic sensors of various types of optical fibers continues to develop, this is evidenced by many studies on fiber optic sensors conducted and published in international journals including the use of optical sensors to detect the purity of honey in distilled water [1], fiber sensors taper for glucose detection [2] and detection of $\mathrm{NaCl}$ salts using optical fiber sensors [3].
Research on the use of fiber optic sensors using fiber optic bundles to detect cholesterol solution concentration has also been carried out [4-6]. The results of the sensitivity of the use of fiber optic research is one example of the utilization Gaussian beam assumption upon the fact that there are still shortcomings. It is expected that future research about the use of optical fiber and its sensitivity increases assuming that quasi-Gaussian beam on the detection of concentrations of cholesterol.

The sensitivity of cholesterol detection results is almost the same and approaches Gaussian beams, such as fast and highly sensitive detection of cholesterol [7], namely magnetite as a platform for detecting materials for glucose, ethanol and cholesterol [8], amperometric glucose detection uses Cobalt (II) Chloride as an electrocatalyst on aprotic media [9], electrochemical sensors are sensitive and selectively use silver nanoparticles [9], electrochemical sensors in films smeared on carbon nanoparticles are translucent to request cholesterol [10], carbon nanotube layers and gold nanoparticles based on bienzyme biosensors are also for cholesterol detection [11], high-performance electrochemical biosensors 
for detecting total cholesterol [12], detection of cholesterol by digitonin conjugated gold nanoparticles[13], electrochemical and optical polymers use biosensors to detect cholesterol [14], detection of cholesterol by digitonin conjugated gold nanoparticles [15], amperometric detection of cholesterol using an indirect electrochemical oxidation method [16], and detection of cholesterol concentration assumes bundle fiber optics using a theoretical analysis of the Gaussian Beam approach [17-19]. But there are other assumptions from the development of the bundle fiber optic shift sensor using the quasi-Gaussian beam approach [20].

The applied articles of this optical fiber sensor have motivated researchers to analyze the sensitivity of the sensor to determine cholesterol concentration through the Gaussian beam approach and quasi-Gaussian beam through mathematical analysis and experimental approaches. The purpose of analyzing the sensitivity of fiber optic sensors using mathematical analysis of two approaches, namely the Gaussian beam approach and the quasi-Gaussian beam compared, to the sensitivity of the optical sensor experimental results so that it can find the correct approach of sensitivity values between theory and experiment. The novelty of fiber optic sensor research is an increase in sensor efficiency with a quasi-Gaussian beam approach through bundle optical fiber. The mathematical approach with quasi-Gaussian can be used as a reference for the intensity and power equation in determining high sensitivity.

\section{METHOD}

This study used mathematical analysis method and experimental method. The initial method with a mathematical description for the description of the bundle optical fiber used in the experiment until the sensitivity equation was obtained. Figure 1 shows the basic scheme of the optical fiber shift sensor, the light source (S) enters the transmitter fiber (TF) and hits the target, and then the light is reflected by the target surface and transmitted back through the fiber receiver (RF) and to the photo detector (D).

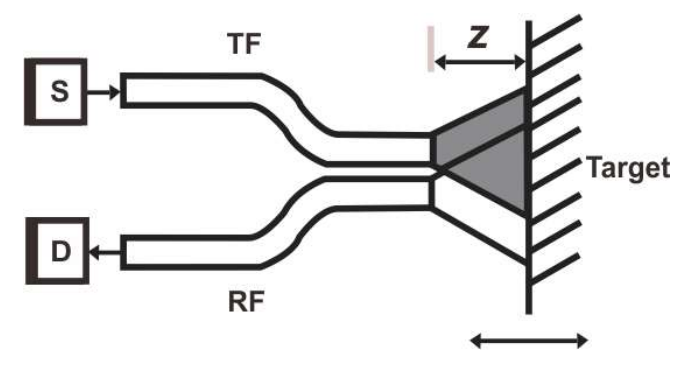

Figure 1. Basic Arrangement of Optical Fibers

The light leaving the fiber transmitter bundle is represented by perfect symmetrical cone with a divergence angle $\theta_{a}$, the center at point $O$ with the distance $z_{a}$ in the bundle fiber (Figure 2a).

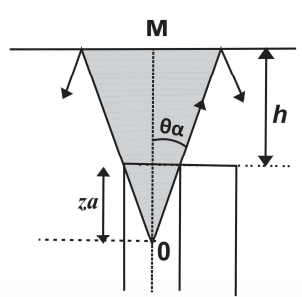

(a)

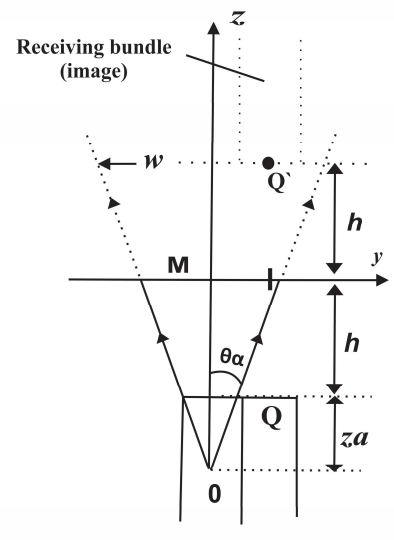

(b)
Figure 2. The Light Cone Beam Coming Out of the Transmitter Fiber (a) Concerning the Mirror and Reflected Back to the Receiving Fiber (b) The Beam Enters the Shadow Receiving Fiber

To determine the beam of light that enters the receiving fiber, it is not necessary to review the reflection beam by the mirror to the receiving fiber. Because the reflector is a flat and perfect mirror, the receiving fiber can be considered as the shadow fiber behind the mirror (Figure $3 b$ ). Now it is introduced that the $z$ coordinate is straight with the 
(longitudinal) axis of the beam cone that starts at 0 and extends to the mirror surface. Center coordinates in $Q^{\prime}$ at the end of the recipient bundle:

$y=2 \omega_{a}$

$z=z_{a}+2 h$

With $h$ is the distance of the shift to be monitored. The approach will be based on electromagnetic waves paraxial Gaussian files. Now that the wave file is viewed with a Gaussian profile, the beam radiation of the emitted beam is not maintained but decreases radially which meets the exponential law, namely:

$I(r, z)=\frac{2 P_{E}}{\pi \omega^{2}(z)} \exp \left(-\frac{2 r^{2}}{\omega^{2}(z)}\right)$

With $r$ being the radial coordinate, $z$ is the longitudinal coordinate and $\omega$ is the file size at distance $z$ which can be written as follows:

$\omega(z)=\omega_{0} \sqrt{1+\left(z / z_{R}\right)^{2}}$

The set $\omega_{0}$ (the radius of the waist of the light file or waist radius) and $Z_{R}$ (the Rayleigh range) are the parameters of the dynamic file that has a relationship with the wavelength of light $\pi \omega_{0}^{2}=\lambda z_{R}$, for the far field of the file center $\left(z>>z_{R}\right)$ the file meets the spherical waveform which is limited by cones which are characterized by the distribution angle as follows:

$\theta_{a} \approx \tan \theta_{a}=\frac{\omega(z)}{z}=\frac{\omega_{0}}{z_{R}}=\frac{\lambda}{\pi \omega_{0}}$

For simplification $\left(z>>z_{R}\right)$ the radiation intensity function can be simplified as follows:

$$
I(r, z)=\frac{2}{z^{2}} \frac{P_{E}}{\pi \theta_{a}^{2}} \exp \left(-\frac{2 r^{2}}{\theta_{a}^{2} z^{2}}\right)
$$

For mirrors at position $h$ from the end of the transmitter fiber and the receiving fiber bundle, there is a relationship $z=z_{a}+2 h$ and $\omega_{a}<r<3 \omega_{a}$, and for the far field it is necessary to assume $z_{a}>>z_{R}$ which is usually suitable for multimode optical fibers with a large numerical aperture value, which is about 0.2 . The optical power entering the receiving fiber is done by integrating the intensity of the beam of light $(I)$ given by equation (5) which includes the cross-sectional area of the bundle Sa:

$$
P(z)=\int_{S_{a}} I(r, z) d S
$$

The first approach used to calculate power in equation (6) is the surface area of the recipient's bundle $S_{a}=\pi \omega_{a}^{2}$, the intensity of the beam of light $I(r, z)$ is kept constant and equal to the value at the center of the bundle (point Q'; $r=2 \omega_{a} \approx 2 \theta_{a} z_{a}$ ), in this case obtained:

$P=I S=\frac{2 P_{E}}{\xi^{2}} \exp \left(-\frac{8}{\xi^{2}}\right)$

With $\quad \xi=z / z_{a}=1+2 h / z_{a}=1+2 h_{N}$, by analyzing the obtained state $\frac{d P}{d \xi}=0$ (i.e. $\left.h_{N}=0.9142\right)$. The power will reach the maximum, by reviewing this, equation (7) can be written in normalized power, as a normalized distance function $\left(h_{N}\right)$ as follows:

$P_{N}=\frac{8}{\xi^{2}} \exp \left(1-\frac{8}{\xi^{2}}\right)$

Equation (8) will be used as the reference to compare the output power of the experimental results, especially for the ends of the fiber bundles in the form of pairs. Graph equation (8) can be seen in Figure 3, the curve shows that the optical fiber output power will increase by increasing the distance of the object shift from the optical fiber bundle, after 
reaching the peak, the output power will decrease exponentially with increasing distance.

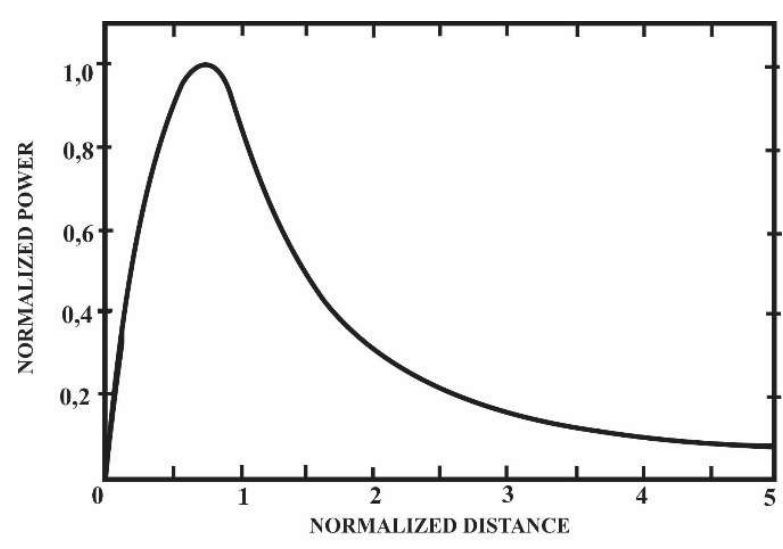

Figure 3. Output Power Normalized to Normalized Shifts

The sensitivity equation of the shift sensor by using a receiver fiber with pair arrangement has been shown and has been derived, while the sensitivity of the shift sensor has been successfully derived [21-25] using 16 recipient fibers with concentric arrangement (Equation 13). Both results of the theory have been successfully tested experimentally using a type of plastic optical fiber. Experimental test results show that the optical fibers with 16 pieces of fiber showed better performance compared to shift sensors with a receiving fiber. Based on the results of a reduction in the sensitivity of the above research, if the number of optical fiber receivers is larger, then the number of beam of light captured by the receiving fiber will be even greater, so that the sensitivity of the sensor will be even higher.

The experimental method was carried out using these research tools including He-Ne lasers (Thorlabs, $632.5 \mathrm{~nm}, 5 \mathrm{~mW}$ ) as electromagnetic waves with wave transmission and reflection properties, optical fiber bundle to guide the wave to the sample, 818-SL (Newport) optical detector to detect reflected waves, chopper and chopper controllers (SR540, Stanford Research
System, Inc.) for wave selection, Lock-in amplifiers (SR510, Stanford Research System, Inc.), flat mirrors as reflected fields, position micrometers (Newport) for shifting distance to solution samples, and computer devices.

The experimental variable of optical fiber cholesterol sensor is the output peak voltage of the sensor (in units of $\mathrm{mV}$ ) in the optical fiber bundle and the concentration of cholesterol (in units of ppm). Furthermore, in the experimental test, the data obtained were in the form of the peak output voltage of the sensor as a function of variation in cholesterol concentration. With this function, the front slope and the back linear area will be determined. Linearity test on the area of front slope and rear slope used linear regression test; both slopes are linear regions, and the area is a sensor working area.

\section{III.RESULTS AND DISCUSSION}

Figure 4 shows the location of the center point of $Q(z, \theta)$ for the receiving fiber (RF) of the fiber bundle with light intensity as it is in the equation (9) for the case of the Gaussian beam and equation (10) for the case of the quasi-Gaussian beam. The Gaussian approach shows the location of point 0 is the light cone point on the transmitting fiber (TF) which is $w / \theta$ to the end surface of the bundle optical fiber with $\theta$ is the angle of divergence. In the quasi Gaussian approach, the angle of divergence changes $\theta(1+\delta)$, with $\delta \neq 0$.

The radiation intensity functions in the Gaussian file is shown in equation (9) and the quasi-Gaussian file in equation (10).

$$
\begin{aligned}
& I_{Q}(z, \theta)=k \frac{P_{T}}{z^{2}} \exp \left\{-2\left|\frac{\theta}{\theta_{a}}\right|^{2}\right\} \\
& I_{Q}(z, \theta)=k \frac{P_{T}}{z^{2}} \exp \left\{-2\left|\frac{\theta}{\theta_{a}(1+\delta)}\right|^{(2+\Delta)}\right\}
\end{aligned}
$$


The normalized power function $P_{N}=P / P_{m a l s}$, as a normalized distance function $\left(h_{N}\right)$ in the Gaussian beam is shown in equation (11) and the quasi-Gaussian beam in equation (12).

$P_{N}=\frac{P_{R}(h)}{P_{r e f}}=2 x \Psi^{2} \exp \left\{1-2|\Psi|^{2}\right\}$

$P_{N}=\frac{P_{R}(h)}{P_{r e f}}=2 x\{(1+\delta) \Psi\}^{2} \exp \left\{1-2|\Psi|^{2+\Delta}\right\}$

with $\Psi, \Psi(h)=2\left\{1+\mu_{2}(1+\delta) \frac{h}{h_{r e f}}\right\}^{-1}$

$P_{n}=1 ; \quad$ if $\quad h=h_{\text {ref }} \quad$ and $\quad \Delta=\delta=0$ for

Gaussian and $\Delta=0.888, \quad \delta=-0.110$ for quasi-Gaussian.

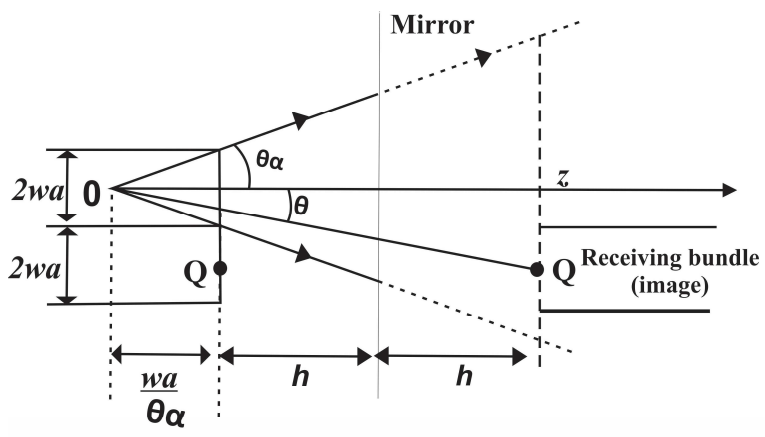

Figure 4. The Light Cone File Coming Out of the

Transmitting Fiber (TF) Hits the Mirror and is

Reflected Back to the Receiving Fiber (RF)

Analysis of sensor sensitivity results using equation (14).

$S=\frac{\partial P_{n}}{\partial h_{n}}$

The normalized power function $\left(P_{n}\right)$ and the shifting function of the normalized distance $\left(h_{n}\right)$ in the Gaussian file are shown in the Equation (15) and (16).
$P_{n}=\frac{P_{R}(h)}{P_{r e f}}=2 \Psi^{2} \exp \left\{1-2 \Psi^{2}\right\} ;$

$\Psi(h)=2\left\{1+\mu_{2} \frac{h}{h_{r e f}}\right\}^{-1} ; h_{n}=\frac{h}{h_{r e f}} ;$

$\Psi=2\left\{1+\mu_{2} h_{n}\right\}^{-1}$

So, $h_{n}=\frac{1}{\mu_{2}}\left(\frac{2}{\Psi}-1\right) ; \quad \partial h_{n}=-\frac{1}{\mu_{2}}\left(\frac{2}{\Psi^{2}}\right) \partial \Psi$

The sensitivity of fiber optic sensors can be determined using equation 4, with;

$\frac{\partial P_{n}}{\partial h_{n}}=\mu_{2} \Psi\left(2 \Psi^{2}-1\right)\left\{2 \Psi^{2} \exp \left(1-2 \Psi^{2}\right)\right\}(17)$

So that, $S=\mu_{2} \Psi\left(2 \Psi^{2}-1\right) P_{n}$

Where $\mu_{2}=\sqrt{8}-1, \quad \Psi=0.707$ and $P_{n}=1$, then the sensitivity value of Gaussian beam is $S=0.0004 \mathrm{mV} \mathrm{ppm}^{-1}$.

The normalized power function $\left(P_{n}\right)$ and the shifting function $\Psi(h)$ of the normalized distance $\left(h_{n}\right)$ in the quasi-Gaussian file are shown in the following equation:

$$
\begin{aligned}
& P_{n}=\frac{P_{R}(h)}{P_{r e f}}=2\{(1+\delta) \Psi\}^{2} \exp \left\{1-2 \Psi^{2+\Delta}\right\} \\
& \Psi(h)=2\left\{1+\mu_{2}(1+\delta) \frac{h}{h_{r e f}}\right\}^{-1} ; h_{n}=\frac{h}{h_{r e f}}
\end{aligned}
$$

and $\Psi=2\left\{1+\mu_{2}(1+\delta) h_{n}\right\}^{-1}$

$h_{n}=\frac{1}{\mu_{2}(1+\delta)}\left(\frac{2}{\Psi}-1\right)$

$\partial h_{n}=-\frac{1}{\mu_{2}(1+\delta)}\left(\frac{2}{\Psi^{2}}\right) \partial \Psi$ 
Equation of quasi-Gaussian sensitivity is obtained,

$S=\mu_{2}(1+\delta) \Psi\left\{(2+\Delta) \Psi^{2+\Delta}-1\right\} P_{n}$

Where $\quad \mu_{2}=\sqrt{8} ; \quad h_{n}=0.914 ; \quad \Delta=0.888$; $\delta=-0.110$; and $P_{n}=1$, then the sensitivity value of quasi-Gaussian beam is $S=0.08 \mathrm{mV} \mathrm{ppm}^{-1}$.

The experimental results of sensitivity detection of cholesterol concentration sensors were obtained by analysis of the experimental data. However, the detector output voltage detection data started when the bundle fiber is placed coincides with the mirror, which is at shift $z=0$. The bundle fiber was placed on a micrometer where the position is shifted every $50 \mu \mathrm{m}$. In each shift position, the detector output voltage was measured to obtain the maximum output voltage from each variation in cholesterol concentration. The results of the study of detection of cholesterol concentration in standard cholesterol samples obtained a sensitivity approach close to the sensitivity value of quasi-Gaussian beam [26]. This study presents the results of further research for more complex cholesterol samples, namely cholesterol samples plus cupric acid solutes with varying values. There is a graph of the maximum output voltage value of the variation in cholesterol concentration as shown in Figure 5.

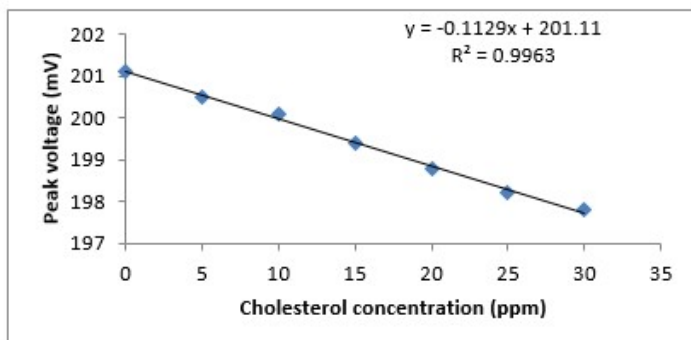

Figure 5. Maximum Voltage Curve for Cholesterol Concentration in Seven Samples
Figure 5 shows a graph of the relationship of the maximum output voltage of the seven samples of cholesterol concentration from 0 to $30 \mathrm{ppm}$. The maximum output voltage of each sample were measured from optical detectors with the manipulation of the distance towards the samples. The maximum output voltage indicates a decrease in linear seven concentration samples against cholesterol. The results of detection analysis showed that the maximum output voltage had a linear decrease in the concentration of cholesterol solution with a sensitivity of $0.1129 \mathrm{mV}$ $\mathrm{ppm}^{-1}$ and linearity of $99.63 \%$.

The form of normalized power curve, as a normalized distance function $\left(h_{N}\right)$, is used to compare the output power output of the experimental results, Gaussian files and quasi-Gaussian files, especially for the ends of the fiber bundles in the form of pairs as it is presented in Figure 6. The curve shows that the optical fiber's output power will increase as increasing bundle optical fiber shift distance, after reaching peak, output power will decrease exponentially with increasing distance.

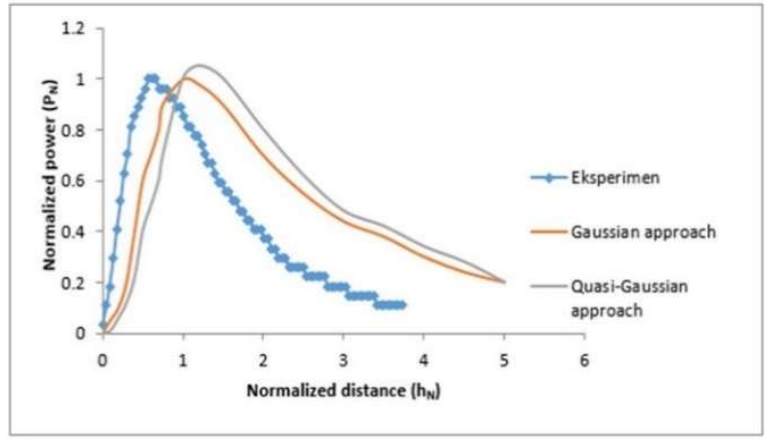

Figure 6. Graph of power output is normalized to normalized shiftsexperimental results, Gaussian beam, and quasi-Gaussian beam

Figure 6 shows the sensitivity curve of a power change against normalized distance normalized. The curve shows the approach slopes between Gaussian beam with quasi-Gaussian experimental results. The 
Jurnal Penelitian Fisika dan Aplikasinya (JPFA), 2019; 9(1): 22-31

results of the sensitivity analysis mathematically obtained the Gaussian beam sensitivity value of $0.0004 \mathrm{mV} \mathrm{ppm}^{-1}$, the sensitivity of the quasi-Gaussian beam is $0.08 \mathrm{mV} \mathrm{ppm}^{-1}$, and the sensitivity analysis is experimentally obtained $0.11 \mathrm{mV} \mathrm{ppm}^{-1}$.

\section{IV.CONCLUSION}

Gaussian beam and quasi-Gaussian beam mathematical approach can be used as a reference for the intensity and power equation in determining high sensitivity. The elemental sensing experiment validation can be used to determine the output voltage value (maximum) as a concentration function based on shift profile between fiber optic probes and cholesterol samples. Shifting the tip of the fiber optic to the reflecting plane can receive the maximum reflected laser beam by the fiber receiving and produce higher efficiency. Sensitivity through mathematical analysis using the quasi-Gaussian $S=0.08 \mathrm{mV} \mathrm{ppm}^{-1}$, and the quasi-Gaussian approach is higher than the sensitivity in the Gaussian $S=0.0004 \mathrm{mV} \mathrm{ppm}^{-1}$. Based on the output power profile, sensor performance, and sensitivity through the flat mirror reflection field, it can be concluded that the sensitivity of the optical fiber sensor is closer to the sensitivity of the quasi-Gaussian beam to determine cholesterol concentration.

\section{ACKNOWLEDGMENT}

The authors would like to acknowledge Airlangga University to provide Optical Laser Laboratories. We also thank Yosep and M. Fajar as the laboratory assistants who have assisted in the procurement of optical sensor devices for this research.

\section{REFERENCES}

[1] Hida N, Bidin N, Abdullah M, and Yasin M. Fiber Optic Displacement Sensor for Honey Purity Detection in Distilled Water. Optoelectronics and Advanced Materials.
2013; 74(8): 565-568. DOI: https://doi.org/10.11113/jt.v74.4711.

[2] Yasin M, Ahmad H, Thambiratnam K, Jasim AA, Phang SS, and Harun SW. Design of Multimode Tapered Fibre Sensor for Glucose Detection. Optoelectronics and Advanced Materials. 2013; 7(5-6): 371-376. Available from:

https://www.researchgate.net/publication/26 4768406 Design_of multimode tapered fi bre sensor for glucose detection.

[3] Rahman HA, Harun SW, Yasin M, and Ahmad H. Fiber Optic Salinity Sensor Using Fiber Optic Displacement Measurement with Flat and Concave Mirror. IEEE Journal of Selected Topics in Quantum Electronics. 2012; 18(5) :1529-1533. DOI: http://dx.doi.org/10.1109/JSTQE.2011.2159 705.

[4] Budiyanto M, Suhariningsih, and Yasin M. Cholesterol Detection Using Optical Fiber Sensor Based On Intensity Modulation. Journal of Physics : Conference Series. 2017; 853: 012008. DOI:

https://doi.org/10.1088/1742-6596/853/1/01 2008.

[5] Budiyanto M, Suhariningsih, and Yasin M. Optical Fiber Displacement Sensor Using Concave Mirror for Cholesterol Detection. IEEE Proceeding. 2017; 150-153. DOI: https://doi.org/10.1109/ISSIMM.2017.81242 $\underline{81}$.

[6] Budiyanto M, Suhariningsih, and Yasin M. Potency of Sensor Displacement Detection of Cholesterol Concentration Using Flat Mirror as Media for Learning Waves and Optics. Journal of Physics : Conference Series. 2018; 1006: 012007. DOI: http://doi.org/10.1088/1742-6596/1006/1/01 2007.

[7] Ruechaa N, Siangproh W, and Chailapakul O. A Fast and Highly Sensitive Detection of Cholesterol Using Polymer Microfluidic Devices and Amperometric System. Talanta. 
Jurnal Penelitian Fisika dan Aplikasinya (JPFA), 2019; 9(1): 22-31

2011; 84(5): 1323-1328. DOI:

https://doi.org/10.1016/j.talanta.2011.02.040.

[8] Jaime J, Rangel G, Munos-Bonilla A, Mayoral A, and Herrasti P. Magnetite as a Platform Material in the Detection of Glucose, Ethanol and Cholesterol. Journal Sensors and Actuators B: Chemical. 2017; 238: 693-701. DOI:

https://doi.org/10.1016/j.snb.2016.07.059.

[9] Kozitsina AN, Okhokhonin AV, and Matern AI. Amperometric Detection of Cholesterol Using Cobalt (II) Chloride as an Electrocatalyst in Aprotic Media. Journal of Electroanalytical Chemistry. 2016; 772: 89-95. DOI:

https://doi.org/10.1016/j.jelechem.2016.04.0 29.

[10] Nantaphola S, Chailapakul O, and Siangproh W. Sensitive and Selective Electrochemical Sensor Using Silver Nanoparticles Modified Glassy Carbon Electrode for Determination of Cholesterol in Bovine Serum. Sensors and Actuators B: Chemical. 2015; 207(A): 193-198. DOI:

https://doi.org/10.1016/j.snb.2014.10.041.

[11] Ji J, Zhou Z, Zhao X, Sun J, and Sun X. Electrochemical Sensor Based on Molecularly Imprintedfilm At $\mathrm{Au}$ Nanoparticles-Carbon Nanotubes Modified Electrode for Determination of Cholesterol. Biosensors and Bioelectronics. 2015; 66: 590-595. DOI:

https://doi.org/10.1016/j.bios.2014.12.014.

[12] Cai X, Gao X, Wang L, Wu Q, and Lin X. A Layer-By-Layer Assembled and Carbon Nanotubes/Gold Nanoparticles-Based Bienzyme Biosensor for Cholesterol Detection.Sensors and Actuators. 2013; 181: 575-583. DOI:

https://doi.org/10.1016/j.snb.2013.02.050.

[13] Ahmadalinezhad A and Chen A. High-Performance Electrochemical Biosensor for the Detection of Total Cholesterol. Biosensors and Bioelectronics.
2011; 26(11): 4508-4513. DOI:

https://doi.org/10.1016/j.bios.2011.05.011.

[14] Soylemez S, Udum YA, Kesik M, Hizliates CG, Ergun Y, and Toppare L. Electrochemical and Optical Properties of a Conducting Polymer and Its Use in a Novel Biosensor for the Detection of Cholesterol. Sensors and Actuators. 2015; 212: 425-433. DOI: https://doi.org/10.1016/j.snb.2015.02.045.

[15] Raj V, Jaime R, Astruc D, and Sreenivasan K. Detection of Cholesterol by Digitonin Conjugated Gold Nanoparticles. Biosensors and Bioelectronics. 2011; 27(1): 197-200. DOI: https://doi.org/10.1016/j.bios.2011.06.015.

[16] Wei-Hung C, Po-Yen Chen, Po-Chin Nien, and Kuo-Chuan Ho. Amperometric Detection of Cholesterol Using an Indirect Electrochemical Oxidation Method. Steroids. 2011; 76(14): 1535-1540. DOI:

https://doi.org/10.1016/j.steroids.2011.09.00 3.

[17] Faria JB. A Theoretical Analysis of The Bifurcated Fiber Bundle Displacement Sensor. IEEE Transactions on Instrumentation and Measurement. 1998; 47: 742-747. DOI:

https://doi.org/10.1109/19.744340.

[18] Sastikumar D, Gobi G, and Renganathan B. Determination of The Thicness of a Transparent Plate Using a Reflective Fiber Optic Displacement Sensor. Optics \& Laser Technology. 2010; 42(6): 911 - 917. DOI: https://doi.org/10.1016/j.optlastec.2010.01.0 08 .

[19] Swatland HJ. Effect of Connective Tissue on the Shape of Reflectance Spectra Obtained With A Fibre-Optic Fat-Depth Probe in Beef. Meat Science. 2001; 57(2): 209-213. DOI: https://doi.org/10.1016/S0309-1740(00)0009 5-4.

[20] Faria JAB. Modeling the $\gamma$-Branched Optical Fiber Bundle Displacement Sensor Using a 
Jurnal Penelitian Fisika dan Aplikasinya (JPFA), 2019; 9(1): 22-31

Quasi-Gaussian Beam Approach. Microwave and Optical Technology Letters. 2000; 25(2): 138-141. DOI:

https://doi.org/10.1002/(SICI)1098-2760(20 000420)25:2\%3C138::AID-MOP16\%3E3.0. $\mathrm{CO} ; 2-\mathrm{F}$.

[21] Yasin M, Harun SW, Kusminarto, Karyono, Zaidan A, Thambiratnam K, and Ahmad H. Design and Operation of a Concentric Fiber Displacement Sensor. Fiber and Integrated. 2009; 28(4): 301-309. DOI: http://dx.doi.org/10.1080/014680309028426 $\underline{73}$.

[22] Rahman HA, Harun SW, Norazlina S, Yasin M, and Ahmad H. Fiber Optic Displacement Sensor for Temperature Measurement. IEEE Sensors Journal. 2012; 12(5): 1361-1364. DOI:

http://dx.doi.org/10.1109/JSEN.2011.21724 $\underline{09}$.

[23] Samian and Zaidan A. Detection of Rhodamine B Levels in Destilled Water Based on Displacement Sensor Using Fiber Coupler and Concave Mirror.Journal Optoelectron. 2016; 18(11-12): 988 - 992. Available from:

https://www.researchgate.net/publication/31
206819ZWRxs5wXu8fnzi2oHAxu7sYKoihj AhXXqFuLNjvUhA1HFHkvo5cxPGPKQc wmVWnsiKnZ6VWN8hrtCM2BcF674KfW H48DuaLh.100148163.100148163.1001481 63.100148163upler_and_concave_mirror.

[24] Yasin M, Harun SW, Kusminarto, Karyono, and Ahmad H. Construction of Fiber Optic Sensor for Micro-Displacement Measurement Based on Refelctive Intensity Modulation Techniuque. $2^{\text {nd }}$ Jogja International Physics Conference. Yogyakarta; 2007.

[25] Yasin M, Soelistiono S,Yhuwana YGY, Khasanah M, Arof H, Irawati N, and Harun SW. Intensity Based Optical Fiber Sensors for Calcium Detection. Optoelectronics Advance Materials Rapid Communications. 2015; 9(9-10): 1185-1189. Available from: https://oam-rc.inoe.ro/index.php?option=ma gazine \&op=view\&idu=2688\& catid=92.

[26] Budiyanto M, Suhariningsih, and Yasin M. Efficiency of Optical Sensors with Quasi Gaussian Beam for Determining Cholesterol Concentration. Proceedings of the International Conference on Science and Technology (ICST 2018). 2018; 70-73. DOI: https://dx.doi.org/10.2991/icst-18.2018.15. 